\section{СПИСОК ВИКОРИСТАНОЇ ЛІТЕРАТУРИ}

1. Великий тлумачний словник сучасної української мови / уклад. та гол. ред. В. Т. Бусел. Київ = Ірпінь : Перун, 2005. - VIII. -1728 с.

2. Гончаренко С. У. Український педагогічний енциклопедичний словник / С. У. Гончаренко. - Вид. 2-е, доповнене й виправлене. - Рівне : Волинські обереги, 2011. - 552 с.

3. Калініченко Н. Василь Сухомлинський та проблема розумового виховання школярів / Н. Калініченко // Рідна школа. - 2013. - № 8-9. - С. 16-19.

4. Падалка О. С. В. О. Сухомлинський - визнаний у світі педагог і вчений / О. С. Падалка // Свропейські педагогічні студії. - 2013. - Вип. 3-4. - С. 81-102.
5. Савченко О. Я. Дидактика початкової освіти : підруч. для вищ. навч. закл. / О. Я. Савченко. - Вид. 2. К. : Грамота, 2013. - 504 c.

6. Савченко О. Я. Розвиток особистості школяра стрижнева проблема творчості В. О. Сухомлинського / О. Я. Савченко // Освіта. - 2013. - 18-25 верес. - С. 6-7.

7. Сухомлинський В. О. Розмова з молодим директором / В. О. Сухомлинський // Вибрані твори : в 5 т. - К., 1977. - Т. 4. - С. 394-626.

8. Сухомлинский В. А. Сердце отдаю детям / В. А. Сухомлинский. - К. : Рад. шк., 1988. - 272 с.

9. Сухомлинський В. О. Сто порад учителеві / В. О.Сухомлинський//Вибрані твори : в 5 т.-К., 1976.T. 2. - C. 419-654.

Дата надходження до редакиї: 25.06.2019 p.
УДК 37.015.3:[159.922.73:316.613.434]

DOI: 10.37026/2520-6427-2019-99-3-80-86

\section{Олена КОНОНКО,}

докторка психологічних наук, професорка, завідувачка кафедри дошкільної освіти Ніжинського державного університету імені Миколи Гоголя

\title{
ДИТЯЧА АГРЕСІЯ: СПЕЦИФІКА, ПРИЧИНИ ВИНИКНЕННЯ, ВИХОВАННЯ ВМІННЯ ЇЇ ДОЛАТИ
}

У статті представлено кониептуальний підхід щзодо вивчення агресії як феномена особистісного зростання в ранньому онтогенезі. Розкрито суть та специфіку агресивності в дошкільному дитинстві, зокрема визначено внутрішні та зовнішні чинники ї виникнення як негативної якості особистості. Охарактеризовано зміст поняття "вміння дошкільника долати агресію», розроблено його типологію та сформульовано педагогічні умови ефективного виховання означеного вміння в дітей стариого дошкільного віку.

Ключові слова: агресія, агресивна поведінка, особистісне зростання, внутрішні та зовнішні чинники, вміння долати агресію, педагогічні умови оптимізації виховного процесу.

В статье представлен кониептуальный подход к изучению агрессии как феномена личностного роста в раннем онтогенезе. Раскрыты суть и специфика агрессивности в дошкольном детстве, в частности определены внутренние и внешние факторы ее возникновения как негативного качества личности. Охарактеризовано содержание понятия «умение доикольника преодолевать агрессию», разработана его типология и сформулированы педагогические условия эффективного воспитания определенного умения у детей старшего дошкольного возраста.

Ключевые слова: агрессия, агрессивное поведение, личностный рост, внутренние и внешние факторы, умение преодолевать агрессию, педагогические условия оптимизации воспитательного процесса.
The article substantiates the theoretical and methodological principles of studying aggression as a phenomenon of personal growth; the essence and specificity of aggressiveness in preschool children are revealed; internal and external factors of occurrence of the specified negative quality are determined. Aggression is defined as purposeful destructive behavior of the preschool child, which contradicts the moral norms and inflicts physical harm or causes the victim negative experiences, the state of tension, fear, sadness. The author describes the concept of "ability to overcome aggression» is introduced by the author, the concept of development of a given skill in children of the preschool age is developed through the prism of the subjective approach. Qualifying a child 5-7 years as an active subject of life activity, the ability to overcome aggression is defined as the integral characteristic of the individual, the formation of which is defined by the ability to analyze the situation and their actions, the ability to more or less objectively evaluate the negative effects of aggressive behavior; the ability to make voluntary efforts to curb aggression and overcome negative impulses; the ability to competently and decently make their way out of a conflict situation. These served as criteria for assessing types of aggression curbing in children of preschool age while interacting with their peers. Four types of the investigated skill are distinguished and characterized - constructive, destructive, conformal and contemplative. In the experimental group, only $22.4 \%$ of children have been found to be of constructive type, 
they were distinguished by active in the form and moral content of the position in relation to peers; balance of knowledge, moral attitude and ability to resolve conflicts expediently and peacefully. Other $77.6 \%$ of preschool children were either characterized by an imbalance of dominant characteristics of the ability to overcome aggression or passivity of the position. The conditions for optimization of the educational process were: enriching the knowledge of preschoolers about the causes and consequences of aggressive behavior; exercises in the ability to construct peace-loving, friendly relations with peers; creation of an environment encouraging family values in pre-school institutions through the use of modern educational technologies

Key words: aggression, aggression, personal growth, internal and external factors, ability to overcome aggression, pedagogical conditions of optimization of educational process.

Постановка проблеми. У сучасних соціальних реаліях актуалізується проблема розвитку в дошкільників елементарних форм самоконтролю та саморегуляції поведінки, формування здатності поводитися адекватно, виявляти «здорову» міру довіри оточуючому світу та самому собі. На часі виховання в ранньому онтогенезі вміння самовиражатися в соціально прийнятний спосіб, реалізувати себе, утримуватися від негативних проявів поведінки. У контексті вищеозначеного зауважимо, що однією з актуальних $\epsilon$ проблема дитячої агресивності, яка потребує поглибленого вивчення. Зокрема, іiі важливість для педагогічної теорії та практики пов'язана 3 тим, що ситуативні прояви агресивної поведінки дошкільників 3 часом можуть перетворитися на стійкі особистісні утворення.

Сьогодні дитина живе і формується як особистість в агресивному середовищі, яке надто жорстко унормовує життя, регламентує вимоги, визначає межі, контролює поведінку, використовує каральний інструментарій. Ускладнюється життя дитини XXI століття і тим, що з кожним днем набувають усе більшого значення конкурентні, змагальні тенденції в освіті, порівняння між собою різних за здібностями, темпераментами, ціннісними орієнтаціями осіб. Заохочення лідерських якостей, високих досягнень за будь-яку ціну, підтримка індивідуалістичної спрямованості також ускладнюють дошкільникові і без того непростий процес соціалізації, гармонійного входження у «широкий» світ, актуалізують необхідність плекання позитивних життєвих вражень.

Щоб дитина дошкільного віку могла повною мірою реалізувати свій природний потенціал, не обмежуючи при цьому інтересів інших людей, не порушуючи моральних норм та не «виходячи із себе», iіi необхідно цьому навчати, зокрема вправляти в умінні проявляти терплячість, витримку, емоційну сприйнятливість, пояснювати доцільність коректної, неагресивної поведінки в конфліктних ситуаціях, аналізувати наслідки гуманної та агресивної поведінки.

Аналіз наукових досліджень і публікацій. Вивченню феномена «агресія», а також видів агресивної поведінки присвячено дослідження Г. Андреєвої, Н. Барчанкової, О. Басса, Г. Лаврентьєвої, В. Лебединського, О. Нікольської, А. Реана, А. Романова, Л. Семенюк, I. Фурманова, Г. Широкої й інших вітчизняних і зарубіжних психологів та педагогів.
За даними провідних фахівців, прояви агресії - одна 3 доволі поширених у дошкільному віці проблем. На цьому наголошують у своїх дослідженнях О. Личко, О. Монахов, І. Овчаренко, Т. Рум'янцева та ін., зауважуючи, що ті чи інші форми агресивності притаманні більшості 5-7-річних дітей. За даними їх досліджень, із засвоєнням основних моральних правил і норм поведінки у багатьох старших дошкільників прояви агресивності поступаються просоціальним формам. Водночас дослідники звертають увагу на те, що в деяких дітей означеної вікової категорії агресія як стійка форма поведінки не лише зберігається, а й розвивається, трансформуючись у стійку негативну якість особистості. Наслідком цього $є$ деформація особистісного розвитку, звуження можливостей повноцінного спілкування з однолітками.

Більшість провідних фахівців під агресивністю розуміють цілеспрямоване нанесення дитиною фізичної або психологічної шкоди іншій особі, а під агресивною поведінкою - спосіб дій, в якому проявляється агресія. Зважаючи на це, І. Дубровіна, Т. Лаврентьєва, Т. Марцинковська, Н. Микляєва, Т. Чиркова та ін. переконують, що профілактична та корекційна робота 3 агресивними дітьми насамперед має бути спрямована на ліквідацію причин відповідної поведінки

Наявна чимала кількість різних трактувань щодо понять «агресія» та «агресивна поведінка». Так, під першим, наприклад, розуміють: реакцію, що шкодить іншому (А. Басс); нанесення шкоди живим та неживим об’єктам (Е. Фромм); наступальні й насильницькі дії, спрямовані на населення шкоди або знищення об'єкта (В. Овчаренко); цілеспрямовану руйнівну дію, що суперечить суспільним нормам і правилам, шкодить об’єктам нападу, викликає дискомфорт (Л. Семенюк).

Ураховуючи певні відмінності в трактуванні, всі означені вище фахівці одностайні в тому, що агресія це не вроджена біологічна реакція, а форма поведінки дитини, обумовлена соціальними зв'язками та відносинами.

У нашому дослідженні під «агресією» ми розуміємо цілеспрямоване нанесення дошкільником фізичної або психологічної шкоди однолітку, а під «агресивною поведінкою»- спосіб дій, в яких проявляється агресія.

Дані дослідження А. Реана, Т. Рум'янцевої, О. Фурмана та інших фахівців дозволяють виокремити низку взаємопов'язаних чинників, які обумовлюють прояви деструктивної форми дитячої агресії, як-от:

- індивідуальний чинник - біологічні та психологічні передумови асоціальної поведінки, що ускладнюють адаптацію дитини до життя в соціумі;

- педагогічний чинник - недоліки сімейного та суспільного виховання;

- соиіально-психологічний чинник - несприятливі особливості взаємодії дитини із найближчим оточенням (батьками, педагогами, колективом однолітків);

- особистісний чинник - система ціннісних орієнтацій, особливості світобачення, розвиток саморегуляції;

- соиіальний чинник - матеріальне та фінансове забезпечення родини, рівень ії культури, освіти, коло інтересів $[4 ; 5 ; 9]$.

Основними причинами агресивної поведінки дитини дошкільного віку Н. Барченкова та Н. Суворова визначають: нестачу любові значущих дорослих, передусім батьків; прагнення дитини до автономії, незалежності; невміння дошкільника правильно 
поводитися в конфліктній ситуації, застосування агресивності як захисної реакції; дисгармонійний розвиток внутрішнього світу, несформованість адекватної самооцінки, «Я-концепції»; труднощі в спілкуванні 3 однолітками; невміння домагатися високих результатів діяльності; втома, перенапруження, погане самопочуття [1].

Аналіз психолого-педагогічної літератури засвідчує, що фахівцями у дослідженні феномена агресії надається перевага аналізу форм агресивної поведінки дошкільників, визначенню ії чинників, а також особливостям корекційної роботи 3 даною категорією дітей. Однак нами практично не було виявлено досліджень із вказаної проблеми, які б акцентували увагу на дошкільникові 5-7 років як активному суб 'єкті, здатному впливати на власну емоційно-вольову сферу, утримувалися від агресивних проявів щодо однолітків. Недостатня теоретико-експериментальна розробка питання агресивності в контексті проблеми суб'єктності обумовлює правомірність та доцільність організації дослідження, спрямованого на визначення сутності поняття «вміння долати агресію» та педагогічних умов щодо його формування в дітей старшого дошкільного віку.

Мета статті - обгрунтувати концептуальні підходи до проблеми виховання в дітей дошкільного віку вміння долати агресію; охарактеризувати типи, визначити педагогічні умови щодо його ефективного виховання.

Виклад основного матеріалу Теоретико-методологічну основу дослідження становлять підходи: системний (К. Абульханова-Славська, Б. Ананьєв, Л. Виготський, В. Ільїн), діяльнісний (О. Леонтьєв, C. Рубінштейн), особистісно орієнтований (I. Бех, В. Сластьонін), аксіологічний (Т. Поніманська, О. Сухомлинська); фундаментальні положення психолого-педагогічної науки про особливості розвитку особистості в дошкільному віці (Л. Виготський, Д. Ельконін, О. Запорожець, О. Кононко); теоретичні підходи до формування емоційно-вольової сфери в ранньому онтогенезі (Г. Бреслав, В. Вілюнас, О. Запорожець, В. Котирло, О. Смирнова); основні ідеї гуманістичної педагогіки (Ш. Амонашвілі, Г. Балл, В. Сухомлинський); доробок фахівців із проблеми агресії та визначення чинників її виникнення (Г. Андреєва, В. Лебединський, Л. Семенюк); положення щодо специфіки агресії в ранньому онтогенезі, іiі профілактики та корекції (Н. Бурчакова, І. Дубровіна, I. Овчаренко,Т. Рум’янцева).

Найбільш прийнятним вважаємо визначення агресивності, запропоноване Г. Коджаспіровою, яка кваліфікує іiі як цілеспрямовану деструктивну поведінку, що суперечить нормам і правилам існування людей у суспільстві та наносить фізичної школи або викликає негативні переживання, продукує стан напруженості, страху, пригніченості [3].

3 огляду на вищеозначене, в нашому дослідженні під «агресивною поведінкою дошкільника» розуміємо специфічну форму його дій, завдяки яким він демонструє переваги у силі або використовує силу стосовно інших дітей, прагне нанести шкоди. Водночас, кваліфікуючи агресивну поведінку дошкільника як феномен особистісного зростання, звертаємо увагу на його складність, адже не кожен прояв агресивної поведінки дитини слід однозначно оцінювати як негативний. Виникаючи в критичній ситуації, агресія виконує захисну функцію, допомагає дитині мобілізуватися для розв'язання проблеми.
Безумовно, емоції злості й гніву зазвичай «запускають» агресію, мов іржа, «роз'їдають» особистість із середини. Водночас ця емоція є своєрідною внутрішньою мобілізаційною силою, що «підживлює» процес самоствердження.

Ми диференціюємо агресію-мобілізацію, агресію-захист, агресію-загрозу, агресію-насильство. Перший та другий типи агресії слугують радше механізмами актуалізації дитиною власних резервних можливостей із метою досягнення бажаного, протиставлення власної активності войовничій позиції оточення, реакцією на відчуття загрози. Час від часу, не маючи наміру будь-кому заподіяти шкоду, дитина всього лиш демонструє свою готовність дати відсіч, використовуючи з цією метою відповідну міміку, попереджувальні жести. Водночас дослідження засвідчує, що досить часто діти 5-7 років вдаються до реального насильства, агресивної поведінки - відкритої чи прихованої.

Отже, визначаючи рівень агресивності конкретного дошкільника, можна виокремити такі типи прояву агресії:

- орієнтація на утвердження власних можливостей - енергійна мобілізація сил у конфліктній ситуації, що засвідчує намір задовольнити особисті потреби у змаганні (конкуренції) із сильним суперником, відстояти свої права, самоствердитися, проявити самоповагу, досягти успіху;

- орієнтація на проектування загрози - активізація установки «кращий засіб оборони - напад», проте обережний і дистанційний; проявляється переважно у словах-залякуваннях, загрозливому виразі обличчя та жестів, обіцянках покарати тощо;

- орієнтація на тиск і приниження іншого - злісна, ворожа поведінка, бажання реально заподіяти біль іншому, отримати задоволення від цього, використати силові методи, вдатися до різних форм насилля;

- орієнтаиія на самоусунення від конфлікту уникнення конфліктів, ухиляння від необхідності проявити власну волю, поставити агресора «на місце», прийняти власне рішення у конфліктній ситуації, підкорення сильнішому, підлабузництво, звичка вдавати із себе жертву.

У ході вивчення феномена дитячої агресії (у дослідженні взяли участь вихованці закладу дошкільної освіти № 667 м. Києва) ми передусім базувалися на узагальненнях М. Лісіної, Г. Рузської, О. Смирнової, Н. Скрипник, які акцентують увагу на важливості гуманізації та гармонізації стосунків дошкільників, адже за умови зростання незалежності дітей, укріплення їхніх зв'язків з однолітками, формування потреби в самовираженні та самоствердженні між ними, звичайно, виникають конфлікти, в яких і виявляється дитяча агресія [6;7].

Досліджуючи агресивну поведінку дітей старшого дошкільного віку, звертали увагу на такі її прояви: прагнення домінувати над іншими; імпульсивність, неврівноваженість; низький рівень самоконтролю та саморегуляції; непродуманість учинків; спалахи роздратування, гніву; сумніви, невпевненість у собі, складність прийняття рішень; ігнорування моральних норм і правил поведінки; відсутність страху, почуття провини, каяття за свої вчинки; нездатність розуміти однолітків, ігнорування їхніх переживань; несформованість механізму децентрації, вміння поставити себе на місце іншого. 
У протоколах спостережень, крім означеного вище, у дітей також фіксувалися такі стани: гостре переживання дітьми власного недооцінювання значущими дорослими та однолітками, сприйняття інших дітей як конкурентів, супротивників, перешкод; болісне переживання успіхів інших, неадекватне реагування на них, прояв злорадства в ситуації їхнього неуспіху; використання агресії як засобу протесту під час невдачі, програшу; у будь-який спосіб (навіть асоціальний) привернення до себе уваги однолітків; нездатність адекватно оцінити вчинок, якість, результат діяльності; настороженість, підозрілість, недовіра; неусвідомленість, нерозуміння своєї агресивності та ії̈ наслідків.

На відміну від традиційного підходу до розробки проблеми дитячої агресії, в дослідженні ми акцентуємо увагу не на профілактиці та корекції негативної поведінки дитини, а насамперед на розвитку в неї як носія агресії вміння іï долати. Ми кваліфікуємо дитину старшого дошкільного віку як свідому особистість, активний суб'єкт життєдіяльності та виховного процесу, здатний за певних умов мобілізувати свій потенціал, актуалізувати внутрішні сутнісні сили, виявити довіру власним можливостям, утриматися від негативних проявів. Тобто, йдеться про доцільність упровадження у процес виховання у дітей 5-7-річного віку принципу суб'єктності (за С. Ісаєвим, В. Слободчиковим, В. Татенком) як важливого для його оптимізації.

Орієнтуючись при цьому на принцип суб'єктності, провідним поняттям ми вважаємо «вміння дошкільника долати агресію», під яким розуміємо здатність дитини свідомо аналізувати ситуацію та власні діï, більш-менш об'єктивно оцінювати негативні наслідки власної агресивної поведінки, докладати вольових зусиль для стримування агресії, долання негативних спонук, компетентного й гідного виходу 3 конфліктної ситуації [8].

Таким чином, означені вище принципи слугували нам орієнтирами для визначення критеріїв оцінки міри сформованості в досліджуваних 5-7-річних дітей уміння долати агресію (див. табл. 1).

Таблиия 1

Критерії та показники розвитку

\section{в дітей старшого дошкільного віку вміння долати агресію}

\begin{tabular}{|c|c|}
\hline Критерії & Показники \\
\hline $\begin{array}{l}\text { Здатність аналізувати } \\
\text { та оцінювати ситуацію, } \\
\text { агресивну поведінку, } \\
\text { вміння ї̈ долати }\end{array}$ & $\begin{array}{l}\text { пояснює зміст поняття «агресія», називає причини власної агресивної пове- } \\
\text { дінки, визнає ії негативний вплив на ситуацію та самопочуття (не лише власне, } \\
\text { а й інших людей); адекватно характеризує вміння долати агресію, визначє } \\
\text { його значення в житті, усвідомлює, що йому бракує для оволодіння даним } \\
\text { умінням }\end{array}$ \\
\hline $\begin{array}{l}\text { Докладання вольових зусиль } \\
\text { для стримування агресї̈ } \\
\text { (власної та оточуючих) }\end{array}$ & $\begin{array}{l}\text { у конфліктній ситуації керується здоровим глуздом, контролює та регулює } \\
\text { свої емоції, утримується від образ, погроз, нанесення фізичної або психо- } \\
\text { логічної шкоди; орієнтується на соціально-моральні стандарти поведінки; } \\
\text { належно поводиться за умов відсутності поряд доросли, поважає себе за це }\end{array}$ \\
\hline $\begin{array}{c}\text { Компетентний вихід } \\
\text { із конфліктної ситуації }\end{array}$ & $\begin{array}{l}\text { бере до уваги реальну ситуацію, моральні норми, прагнення і можливості } \\
\text { (власні та однолітків); усвідомлює важливість мирного врегулювання конф- } \\
\text { лікту; готовий до провомірних поступок; визнає свою провину, відстоює } \\
\text { справедливість та власну гідність; здатний приймати компромісні рішенн, } \\
\text { досягати порозуміння, укладати доцільні угоди }\end{array}$ \\
\hline
\end{tabular}

Окрім зазначених вище критеріїв та показників, за якими оцінювалася міра розвитку в дошкільників уміння долати агресію, бралася до уваги його структура: когнітивний (уявлення, знання), емоційно-иіннісний (ставлення) та поведінковий (реальні дії, вчинки) компоненти. При цьому враховувалися стабільність проявів уміння долати агресію в різних життєвих ситуаціях та видах діяльності.

Орієнтуючись на визначені критерії, показники, компоненти, стабільність їх прояву, було виокремлено чотири типи долання агресії дітьми старшого дошкільного віку (див. табл. 2).

Як засвідчують наведені у таблиці дані, менше чверті досліджуваних старшого дошкільного віку характеризуються конструктивним типом долання агресії: керуються здоровим глуздом, у ситуації конфлікту поводяться компетентно, беруть до уваги здібності та бажання однолітків, орієнтуються на моральні норми, використовують мирні засоби та прийоми виходу 3 дискомфортної ситуації. Водночас у $2 / 3$ дітей недостатньо сформоване або зовсім відсутнє вміння конструктивно долати агресію чи мирним способом розв'язувати конфлікт.
Це актуалізує необхідність організації цілеспрямованої виховної роботи з метою поглиблення необхідних знань дошкільників, формування ціннісного самоставлення та гуманного ставлення до однолітків, вправляння в умінні контролювати та регулювати негативні емоції, висловлювання, дії.

За такого підходу до основних педагогічних умов та методів оптимізації виховного процесу нами віднесено:

1. Збагачення знань дошкільників про причини та наслідки їхньої агресивної поведінки для них самих, а також оточуючих (використано дидактичні ігри, бесіди, перегляд мультфільмів, читання художньої літератури відповідної спрямованості)

2. Вправляння дітей в умінні конструювати миролюбні, доброзичливі взаємини з однолітками (застосовано ігри, творчі завдання, психогімнастичні вправи).

3. Створення в дошкільному закладі та сім'ї иіннісного середовища шляхом використання сучасних виховних технологій (проведено тренінги, ділові ігри, консультації, бесіди, батьківські збори, оформлено пам’ятки). 
Кількісний розподіл досліджуваних старшого дошкільного віку за типами уміння долати агресію

\begin{tabular}{|c|c|c|}
\hline $\begin{array}{l}\text { Типи вміння } \\
\text { долати агресію }\end{array}$ & $\begin{array}{c}\text { Характеристика знань, ставлення та поведінки } \\
\text { представників кожного рівня }\end{array}$ & \begin{tabular}{|c|} 
К-ть \\
представників \\
$(\mathbf{y} \%)$ \\
\end{tabular} \\
\hline Конструктивний & $\begin{array}{l}\text { Володіє системою знань про агресію, ії наслідки для оточуючих, важливість } \\
\text { уміння ії долати; з довірою ставиться до себе та інших, цінує чесноти й } \\
\text { визнає недоліки; вирізняєтья оптимістичним самопочуттям, здатністю } \\
\text { регулювати та контролювати свої емоції; утримується від образ та } \\
\text { агресивних дій, не вдається до хитрощів та обману; налагоджує гармонійну } \\
\text { ділову та особистісну взаємодію з однолітками; аргументує власну пози- } \\
\text { цію, бере до уваги думку партнера, узгоджує з ним свої рішення, домов- } \\
\text { ляється про спільні дії; співвідносить бажання із можливостями; прагне } \\
\text { досягти успіху в соціально прийнятний спосіб; у розв’язанні конфлікту } \\
\text { використовує мирні способи і прийоми: доводить правоту, керується здоро- } \\
\text { вим глуздом, у разі потреби йде на поступки, бере до уваги пропозиції } \\
\text { однолітків, дорожить стосунками з ними; у конфліктній ситуації не скар- } \\
\text { житься дорослим, не просить допомоги, розв'язує ііі самостійно; орієн- } \\
\text { тується на моральні норми поведінки, усвідомлює їх доцільність. Знання, } \\
\text { ставлення та поведінка збалансовані, самооцінка адекватна }\end{array}$ & 22,4 \\
\hline Деструктивний & $\begin{array}{l}\text { Володіє знаннями про суть та вплив агресії на стосунки з однолітками; до } \\
\text { оточуючих ставиться } 3 \text { недовірою, до деяких - навіть вороже; прагне } \\
\text { незважаючи ні на що привернути до себе увагу авторитетних людей, } \\
\text { хизується досягненнями, не визнає власних недоліків та прорахунків; } \\
\text { вирізняється нестійкістю емоцій, плинністю настрою, легким переходом } \\
\text { від сміху до злості; здатність контролювати і регулювати емоції та дії } \\
\text { недостатньо розвинена; у спілкуванні прагне домінувати над однолітками, } \\
\text { підкоряти їх собі, диктувати рішення; дратується у разі незгоди однолітків } \\
\text { із вимогою підкоритися; намагається досягти успіху будь-яким способом: } \\
\text { погрожує, відмовляє у прихильності, вдається до хитрощів та неспра- } \\
\text { ведливих звинувачень, скаржиться дорослим. Самооцінка неадекватна, } \\
\text { завищена; знання про моральні норми не узгоджуються зі зневажливим } \\
\text { ставленням до інших та войовничим настроєм }\end{array}$ & 36,2 \\
\hline Конформний & $\begin{array}{l}\text { Знання про агресію та ії негативний вплив на взаємини з оточуючими } \\
\text { людьми схематичні, поверхові; уявлення про важливість уміння долати } \\
\text { агресію недостатньо сформовані; вирізняється песимістичним настроєм, } \\
\text { низькими очікуваннями та домаганнями, неадекватною заниженою само- } \\
\text { оцінкою; прагне не так досягти успіху, як уникнути неуспіху; ставлення } \\
\text { до однолітків здебільшого ситуативне, прагматично мотивоване; пове- } \\
\text { дінка невпевнена; характер учинків залежить від статусу та керівництва } \\
\text { авторитетних дорослих; у взаєминах з однолітками легко поступається } \\
\text { своєю думкою, змінює власні рішення, легко вдається до компромісів, } \\
\text { заради вигоди легко порушує домовленості та угоди, не виконує обіця- } \\
\text { нок; під час конфлікту обирає сторону сильнішого, агресивнішого одно- } \\
\text { літка, може бути знаряддям у його руках. Знання, ставлення та поведінка } \\
\text { недостатньо сформовані }\end{array}$ & 24,8 \\
\hline Споглядальний & $\begin{array}{l}\text { Індивідуаліст, скептик, відсторонений споглядач; чимало часу проводить на } \\
\text { самоті; характеризуєтья інтенсивною пізнавальною активністю; володіє } \\
\text { системою знань про агресію, ії негативні наслідки для оточуючих; має } \\
\text { уявлення про вміння долати агресію та розв’язувати конфлікти мирним } \\
\text { способом; усвідомлює значущість моральних правил та вимог; система } \\
\text { знань є надбанням розуму, не орієнтує на практичні дії, не спонукає до } \\
\text { адекватної поведінки, не стимулює вольової активності; під час конфлікту } \\
\text { залишається споглядачем, аналітиком, коментатором подій; позиція «поза } \\
\text { сутичкою» забезпечує почуття захищеності, безпеки; стратегія «невтру- } \\
\text { чання» засвідчує дисбаланс між наявними моральними знаннями та } \\
\text { практичною бездіяльністю; прагнення до успіху невиразне, приховане, діє } \\
\text { обережно, сумнівається, зважує всі «за» і «проти», прийнятя рішень зазви- } \\
\text { чай дається йому складно, не довіряє оточенню; самооцінка ситуативна, } \\
\text { нестійка. Знання, ставлення та поведінка неузгоджені між собою }\end{array}$ & 16,6 \\
\hline
\end{tabular}


У формувальному етапі експерименту, крім вихованців 5-7-річного віку ЗДО № 667 м. Києва, також узяли участь їхні батьки та вихователі. На основі комплексного підходу, зокрема використання когнітивного, емоційно-ціннісного та поведінкового компонентів щодо вміння долати агресію, було досягнуто позитивних результатів, а саме: знання значної кількості дітей стали більш аргументованими, сис- тематизованими й різнобічними; ставлення певної категорії досліджуваних до однолітків - більш свідомим, диференційованим та гуманним; поведінка частини дошкільників - адекватною, конструктивною, миролюбною.

Пропонуємо порівняльні дані констатувального та контрольного експериментів щодо вміння дітей старшого дошкільного віку долати агресію (див. табл. 3).

Таблиия 3

\section{Динаміка змін у кількісному розподілі дітей старшого дошкільного віку за типами долання агресії на етапах констатації та контролю (у \%)}

\begin{tabular}{|c|c|c|c|}
\hline \multirow{2}{*}{$\begin{array}{c}\text { Типи долання } \\
\text { агресії }\end{array}$} & \multicolumn{2}{|c|}{ Етапи дослідження } & \multirow{2}{*}{ Динаміка } \\
\cline { 2 - 3 } & Констатувальний & Контрольний & \\
\hline Конструктивний & 22,4 & 36,8 & $+14,4$ \\
\hline Деструктивний & 36,2 & 30,4 & $-5,8$ \\
\hline Конформний & 24,8 & 20,2 & $-4,6$ \\
\hline Споглядальний & 16,6 & 12,6 & $-4,0$ \\
\hline
\end{tabular}

Аналіз поданих у таблиці 3 даних засвідчує, що склад дітей, віднесених до конструктивного типу вміння долати агресію, суттєво збільшився за рахунок певного зменшення кількості представників деструктивного, конформного та споглядального типів. Встановлено, що на етапі контролю прогресивні тенденції спостерігаються не в усіх проблемних дошкільників. По-перше, досить консервативними виявилися установки дітей, віднесених до конформного та споглядального типів. По-друге, легше піддавалися виховним впливам знання та уявлення дітей, важче - система цінностей; найбільш консервативними виявилися звички певної категорії дошкільників поводитися у спілкуванні з однолітками упереджено, недовірливо, войовничо. По-третє, роботу щодо виховання в дітей старшого дошкільного віку вміння долати агресію ускладнювали консервативні установки значної кількості батьків, особливо представників сильної статі, які вважають, що агресія в їхніх 5-7-річних дітей не становить загрози, навпаки, вона необхідна для життя в сучасному агресивному суспільстві, свідчить про силу, а також гарантує їм безпеку. Це актуалізує необхідність пролонгації виховної роботи у вказаному напрямі з метою залучення до неї не лише педагогів, а й батьків.

Висновки. Уміння дитини дошкільного віку долати агресію засвідчує позитивну тенденцію її особистісного зростання - активного процесу становлення, в якому вона бере на себе доступну за віком відповідальність за власну життєдіяльність. Уміння долати агресію засвідчується здатністю дитини 5-7 років аналізувати ситуацію, власну поведінку та іiі наслідки; контролювати та регулювати емоції, висловлювання, дії; компетентно і у мирний спосіб розв'язувати конфлікт. Визначено чотири типи сформованості у досліджуваних дошкільного віку уміння долати агресію: конструктивний, деструктивний, конформний і споглядальний. До умов ефективного виховання у дітей 5-7 років вказаного уміння віднесено: збагачення знань дошкільників про причини та наслідки агресивної поведінки; вправляння дітей в умінні конструювати миролюбні, доброзичливі взаємини з однолітками; створення у дошкільному закладі та сім’і ціннісного середовища шляхом використання сучасних виховних технологій.

Перспективними напрямами подалышої нашої роботи вважаємо: розробку, апробацію та впровадження в педагогічну практику моделі ефективного розвитку в дітей дошкільного віку вміння долати агресію; дослідження особливостей становлення даного уміння на різних етапах онтогенезу; вивчення впливу статевої належності на уміння дитини долати агресію; створення методичного забезпечення означених напрямів роботи.

\section{СПИСОК ВИКОРИСТАНОЇ ЛІТЕРАТУРИ}

1. Барченкова Н. И. К проблеме профилактики агрессивного поведения детей старшего дошкольного возраста [Электронный ресурс] / Н. И. Барченкова, М. А. Арсёнова, Н. Н. Суворова // Концепт : научно-методический электронный журнал. - 2013. T. 3. - C. 2671-2675. URL: http://e-koncept.ru/2013/ 53537.htm (дата звернення 10.04.2019).

2. Казаннікова О. В. Психологічний супровід агресивної дитини / О. В. Казаннікова // Проблеми сучасної педагогічної освіти. Педагогіка і психологія. 2013. - № 39 (3). - С. 8-10.

3. Коджаспирова Г. М. Педагогический словарь / Г. М. Коджаспирова, А. Ю. Коджаспиров. - М. : Издательский центр «Академия», 2003. - 176 с.

4. Реан А. А. Агрессия и агрессивность личности / А. А. Реан // Психологический журнал. - 1996. - № 5. C. $3-18$.

5. Румянцева Т. Р. Понятие агрессивности в современной зарубежной психологии / Т. Р. Румянцева // Вопросы психологии. - 1991. - № 1. - С. 30-34.

6. Скрипник Н. І. Виховання толерантних взаємостосунків дітей старшого дошкільного віку : навч.-метод. посіб. / Н. І. Скрипник. - Умань : ПП Жовтий, 2011. - 99 с.

7. Смирнова Е. О. Психологические особенности и варианты детской агрессивности / Е. О. Смирнова // Вопросы психологии. - 2008. - № 1. - С. 42-48.

8. Татенко В. А. Психология отклоняющегося поведения в дошкольном детстве / В. А. Татенко // Воспитание детей дошкольного возраста / под ред. Л. Н. Проколиенко. - К. : Рад. Школа, 1991. C. $83-128$.

9. Фурманов А. И. Детская агрессивность: психодиагностика и коррекция / А. И. Фурманов. - Минск : Ильин В. П., 1996. - 192 с.

Дата надходження до редакиії: 25.06.2019 p. 